\title{
TRANSGENERATIONAL ENTREPRENEURSHIP AND FAMILY CONSTITUTION: AN EXPLORATORY CASE STUDY ANALYSIS
}

\author{
N. Öykü IYYIGÜN ${ }^{1}$
}

\begin{abstract}
Research shows that the majority of family owned businesses are less entrepreneurial, especially after the founder of the business retires/dies. Though it has been agreed on the importance of adopting governance mechanisms and practices for the survival of family businesses, there is still a lack of solidarity and harmony among the family members across generations, which leads to conflicts and causes a major threat to the sustained growth and survival of the business. The aim of this paper is to explore the role of family constitution for transgenerational entrepreneurship in family businesses by examining how family governance practices can strengthen the transgenerational entrepreneurship. In this regard, family constitution of a family owned business located in İmir, was examined and in-depth interviews and exploratory case study analysis from qualitative research methods were applied.
\end{abstract}

Keywords: Family Constitution, Family Businesses, Transgenerational Entrepreneurship, Corporate Governance.

JEL Codes: $M 0, M 1$.

Başvuru: 09.06.2020 Kabul: 27.12.2020

*I would like to thank the reviewers for their valuable comments and suggestions to make this paper more developed and comprehensive.

1 Doç. Dr., İstanbul Ticaret Üniversitesi, İşletme Fakültesi, Uluslararası Ticaret Bölümü, İstanbul, TÜRKIYE, oiyigun@ticaret.edu.tr, https://orcid.org/0000-0003-4708-5825 


\title{
KUŞAKLAR ARASI GİRIŞi̇MCİLIK VE AİLE ANAYASASI: KEŞİFSEL BIR ÖRNEK OLAY ANALIZI
}

\begin{abstract}
$\ddot{O} z$
Aile işletmelerinin özellikle kurucusunun ayrılı̆̆ sonrası çok daha az girişimci olduğu yapılan çalışmalar ile gösterilmiştir. Aile işletmelerinin sürdürülebilirliği açısından yönetişim yapı ve mekanizmalarının önemi konusunda görüs birliği bulunsa da aile üyeleri arasında uyum ve beraberlik eksikliği hala bulunmaktadır. Bu durum hem aile üyeleri arasında çatışma ve karmaşa yaratmakta, hem de aile işletmesinin sürdürülebilir büyüme ve uzun dönemli varlığına ciddi tehdit oluşturmaktadır. Bu çalışmanın amacı, aile işletmelerinde kuşaklar arası girişimcilik açısından aile anayasası ve yönetişim uygulamalarının rolünü analiz etmektir. Bu amaçla İzmir'de bulunan bir aile işletmesinin aile anayasası incelenmiş ve nitel araştırma yöntemlerinden derinlemesine mülakat ve örnek olay analizi tekniği kullanılmıştır.
\end{abstract}

Anahtar Kelimeler: Aile Anayasası, Aile İşletmeleri, Kuşaklar Arası Girişimcilik, Kurumsal Yönetişim.

JEL Kodları: $M 0, M 1$.

"Bu çalışma Araştırma ve Yayın Etiğine uygun olarak hazırlanmıştır."

*Makalenin değerlendirme sürecinde emeği geçen hakemlere yapıcı yorum ve önerileri için teşekkür ederim.

\section{INTRODUCTION}

Family owned businesses are the leading form of business organization in the world. Family businesses stand for 75 percent to 90 percent of all business organizations globally, 70 percent to 80 percent of enterprises in Europe (Yükselen \& Y1ld1z, 2014:15). According to the family business literature, only 30 percent of family owned businesses could survive after the departure of the founder to second-generation (Collins et al., 2016:52). Only 3 percent of all family owned businesses worldwide remain in business for more than three generations. If there is not enough governance within the family members, the family can become a burden on the business (Suess-Reyes, 2017:750).

Family governance can be defined as a process to promote constructive communication between family members that provides an authentic platform for conflict resolution. Family governance practices are considered as catalysts for building a strong family business. It could be found in many studies that family governance practices are positively correlated with financial performance (Berent-Braun \& Uhlaner, 2012:103).

Family's involvement in the governance of the business could be described as one of the most important factors for family businesses. Family control over the business, ownership issues 
and participation in management could vary across generations depending on the family dynamics, age and size of the family and the business (Ramadani et al., 2020:31). A family business could take the first step towards corporate governance by constructing a family constitution which documents the values and principles of the family, characterizes the integrity, provides basis for strategies.

Family businesses are intrinsically heterogenous because of the overlapping dimensions such as family, ownership, and business, which create an interesting area to be analyzed in depth for academics. The aim of this paper is to explore the role of family constitution for transgenerational entrepreneurship in family businesses by examining how family governance practices can strengthen the transgenerational entrepreneurship. In this regard, family constitution of a family owned business located in İzmir, was examined and in-depth interviews and an exploratory case study analysis from qualitative research methods were applied.

The remainder of this paper is structured as follows. The first section presents the theoretical background and literature review. The next section includes methodology and the research findings. The final section provides the discussion and conclusion.

\subsection{Theoretical Background \& Literature Review}

\subsubsection{Family Constitution}

Family is not only the oldest social organization but also the oldest economic organization. Wealth transfer from one generation to the next within the family has been researched by the economists (Chang \& Luo, 2013:174). Due to great role in the economy, family owned businesses are expected to survive and sustain in an efficient way (Yükselen \& Y1ldız, 2014:14).

Family togetherness could be defined as the combination of family resources and involvement of family members. Family togetherness enables family businesses a lot of advantages in the fierce competition (Bhatnagar, 2019:27). Family governance practices provide ground for decreasing conflicts between family members and promoting cohesion (Mustakallio et al., 2002:205). Family involvement makes a conflict in a family business more destructive in comparison with other types because of the difference in value systems (Davies, 2019:168). The value system of a business is based on rationality but the value system of a family is founded on emotional notions.

Family governance not only promotes healthier emotional relationships, but also cultivates loyalty by constructing rules and forming committees to establish the needed basis for family constitution (Koeberle-Scmid, 2018:133). Trust and loyalty could be built through developing a vision by family members by the helps of strong ties and unity (Bhatnagar, 2019:27). To prevent conflict in a family owned business could be realized through a family constitution. 
This may teach family members the importance of listening, taking and giving feedback (Davies, 2019:170).

Family constitution is a crucial strategic tool for not only family governance, but also transgenerational entrepreneurship. Studies show that the family businesses with family constitutions succeed in family succession, transition and governance. Even though a majority of firms in today's global economy are family businesses, there is limited research on the strategic role of the family constitution on transgenerational entrepreneurship.

A family constitution could be defined as a shared statement that summarizes the governance of a family (Koeberle-Scmid, 2018:139). A family constitution could be formed right after the verification of the agreement by the owners of the family business which could be described as family agreement including the structure and the main strategies for the guidance of family and business relationships. One of the most important point for a family constitution is the approval by each member of the family (Arteaga \& Menendez-Requejo, 2017:1).

A family constitution documents the vision and provides perpetuation of family values and a framework for living and working within the family, which forms part of the foundation structure (Jakob, 2020:9). A family constitution establishes not only a benchmark for family members to conform themselves by building decision-making structures and defining responsibilities that constructs unity but also the fundamental strategies by defining the main principles (Koeberle-Scmid, 2018:139).

\subsubsection{New Systems Theory}

The theory of social systems is built on the concept of autopoiesis which was developed by Niklas Luhmann. Humberto R. Maturana and Francisco J. Varela define the term "autopoiesis" as a description of living systems. Autopoiesis (autos meaning self, poiein meaning to produce) means self-reproduction. Autopoietic systems are defined as the systems that reproduce themselves from within themselves (Seidl, 2004:2).

Niklas Luhmann (1984) developed a theory of social systems by re-working on Maturana's definition and claimed that the key of autopoiesis is applicable to biological and non-biological systems. An autopoietic system is expected to reproduce itself by interaction of the system elements (Maturana, 1980:19). Luhmann has transferred the term of autopoiesis to social systems. The autopoiesis has differences in operations of biological and non-biological systems. Being different from organic and neurophysiological systems, social systems are able to orientate their operations to constitute sense by using their operation modus, which is called communication (Wulf, 1999:60).

New systems theory is one of the most important tools to understand the individual and the society, thus it is important to understand and practice the new systems theory for all disciplines that focus on individual. Family businesses are conceptualized as a social system in- 
cluding the family and the business according to the new systems theory. The theory enables a comprehensive understanding of the particularities and complexities of family businesses. The new systems theory defines family business as "a communication system incorporating the decision premises shaped by a family" (Suess-Reyes, 2017:754). At this point it could be stated that family governance as a process is supported by the new systems theory in facilitating communication between family members.

\subsubsection{Transgenerational Entrepreneurship}

Entrepreneurship as a contemporary concept took part in the literature with Schumpeter's definition of entrepreneurs as "innovators, who use a process of shattering the status quo of the existing products and services to set up new products and new services" (Schumpeter, 1934:63; İyigün, 2015:1227). The creation of value through enterprising activities has a great importance in creating generative capability which means "the capacity to renew a firm's operations through innovation in order to create new capabilities" (Zahra, 2005:25).

One of the fundamental components of entrepreneurship is entrepreneurial orientation which could be defined as the behavioral orientation to foster entrepreneurial activities within a business (Lumpkin \& Dess, 1996:136). Kellermanns et al. discuss how innovativeness is achieved in family businesses by featuring the main characteristics of the family influence which could be defined as the family's ability to control the business (Kellermanns et al., 2012:87). These characteristics could be summarized as follows: Family involvement, family control and the reciprocity of the family members (Dao, 2018:66).

The family has a great impact on developing entrepreneurial behaviors through transferring the values by communication (Randerson et al., 2015:144; Sorenson, 2014:463). In other words, family owned businesses try their best to preserve the family values that shows the key role of succession of generations (Tobak et al., 2018:1068).

Transgenerational entrepreneurship paradigm is based on the Resource-Based View (RBV). $\mathrm{RBV}$ is defined as "the processes through which a family uses and develops entrepreneurial mindsets and family influenced resources and capabilities to create new streams of entrepreneurial, financial and social value across generations" (Suess-Reyes, 2017:753; Habbershon et al., 2010:1). Transgenerational entrepreneurship concentrates on creating value for future generations instead of profitability (Nason et al., 2014:3-4).

The adoption of transgenerational entrepreneurship requires succession, transgenerational value creation and preservation that focus on entrepreneurship (Habbershon \& Pistrui, 2002:232). Value creation in transgenerational entrepreneurship is realized for the future family generations rather than the current stakeholders which shows the longitudinal perspective of transgenerational entrepreneurship (Zellweger et al., 2012:137). This emphasis on long-term value creation is crucial for creating competitive advantage. The aim of realizing a vision that transcends pure shareholder value, by not focusing on the short-term 
profit making, is also an important step towards a sustainable family business (Scherrer \& Astrachan, 2018:304). Transgenerational entrepreneurship possesses an entrepreneurial legacy that could be defined as "the narratives of the family's past entrepreneurial behavior or resilience, which motivates generations to engage in strategic activities including strategic education, entrepreneurial bridging, and strategic succession” (Jaskiewicz et al., 2015:2).

As previous research has shown, entrepreneurial orientation is not enough to explain entrepreneurial behaviors in long-lived family businesses. Transgenerational entrepreneurship as a new framework links entrepreneurship theory with family business theory (Randerson et al., 2015:146).

\section{METHODOLOGY}

This paper uses a multi-informant, multigenerational, single-case study approach (Genç \& İyigün, 2011:1128). Data were collected from different sources like in-depth interviews with top executives of a specific family owned business in the hydraulics and pneumatic components industry, observation and archival records. Family constitution of a family owned business located in İzmir, was examined and an exploratory case study analysis from qualitative research methods were applied.

During the research, a series of detailed interviews with the two daughters of the founders (second-generation) namely Sales \& Marketing Director and Executive Board Member and Factory Manager and Executive Board Member who are also shareholders were conducted. Open-ended interview questions were asked to the board members and detailed answers were received during the interviews. Open-ended questions is asked to reach subconscious information by making the respondents speak more about their business (Genç \& İyigün, 2011:1128). Because of the confidentiality, this paper will not use the name of the company; instead it will be called as "The Company".

\section{RESEARCH FINDINGS}

The family constitution of a family owned business located in İzmir, Turkey, was examined and qualitative methods were applied. In this section, findings of in-depth interviews with top executives, observation, family constitution analysis and archival records findings will be presented.

The Company has over 35 years' experience in manufacturing hydraulic and pneumatic components, which was founded by three brothers in İzmir. These three brothers have 5 children (Brother 1: 2 children + Brother 2: 2 children + Brother 3: 1 child) in total. Only two of 
them are working in the family business. In-depth interviews were conducted with these two children actively working in the family business and having managerial roles with executive board memberships. The Company has also a General Manager and a CEO working as a professional, responsible for finance and main administrative tasks with 20 white-collared and 45 blue-collared employees. The Company started to export its products to Italy for the first time in 2004, and since then it has been exporting to more than 30 countries in 5 different continents.

The Company analyzed in the paper, has a family constitution of 71 pages including the appendices, which was a result of a six-month preparation period with a consultancy company and experts (in total 18 months), was enacted in 2018. The constitution has 5 main chapters including general terms \& conditions, conditions regarding the family, conditions regarding the relations between the family and the business, conditions regarding the ownership rights and amendments, revisions and legislation of the family constitution.

The first chapter mentions about the aims of this constitution, which could be summarized as to protect legal transition of the business that was taken from the first generations to future generations and to prepare the business for establishing the needed organizational structure for management. There is a focus on clarifying the distribution of the roles and responsibilities of every individual in the Company. This chapter gives details about the shareholders who do not have managerial roles and are not in the board of directors. It could be seen as a good initiative to give information about the ambiguities in terms of corporate governance principles, namely transparency.

It is important to be clear with the parties of the family constitution. The Company is clear with the parties of the constitution (specifically three founders and two second-generation children actively working in the business with managerial roles). The Company gives the details about the terms and conditions including family businesses, co-founders, assembly of shareholders, family assembly, family council, advisory board and related terms such as share transfer and legal heir.

In every preparation phase of a family constitution, scholars and practitioners try their best to address the following issues (Dirin \& Tutan, 2015:6480; Montemerlo \& Ward, 2005:3-4):

- Extent of the family constitution

- Conflict resolution

- Key elements for decision-making

- Reasons for future issues

- Decision-making process

- Review and revision timing

Parallel with the literature, the second chapter of the family constitution focuses not only on the family values but also on the corporate values. These values are keeping promises, giving 
value to humans and intellectual capital, being honest, fair and legal, keeping spirituality strong, having good communication within the family members, focusing on quality and innovation, prioritizing family commitment, following professional business principles and being respectful to the decision taken by the management. At this point it is evident that the family is successful with the transfer of family values to business values. Family organs could be listed as family assembly, which consists of three co-founders, second-generation children and their wives/husbands and family council, which generally consists of second-generation children. Family assembly meets twice in a year, and the assembly has its own regulations that are attached at the end of the family constitution.

The third chapter focuses on the family management issues specifically family representation in a crisis situation, education and training of next generation family members, management rules related with second-generation family members, anti-competition rule, mediation mechanism, employment policies of family members, succession planning, quality management, corporate social responsibility policies, representation of the Company and corporate governance practices. Education is taken as one of the most important priorities of the Company and it is stated in the constitution clearly. Their own families cover education expenses of the third generations. Third-generation family members are expected to make summer internships in the Company starting from the age of 13, preferably in a different department with their parents to gain consciousness of earning money, to learn how to be responsible and to be able to manage theirselves. It shows the emphasis to training and education given by the second-generation family members. In other words, internal generative capability through value creation across generations, transgenerational entrepreneurship through establishing communication and succession planning are evident by examples in the family constitution.

Management rules for second-generation family members are about the conditions regarding the employment by other businesses. Management rules focus on the role conflicts of the family members such as not being allowed to work in a different business as an executive board member or have a managerial role while working in the family business. If a family member wants to work in a different business instead of the family business, he or she has to resign from all the managerial roles as well as the executive board. There is also one important regulation regarding the competition. Family members are not allowed to establish a business alone or with their cousins in a related industry of the family business; they could only be investors on condition that they are not executive board members in an unrelated industry of the family business with the confirmation of the family assembly. At this point, it could be said that the family business will be run on the cost-benefit analysis with free market principles. For instance, the rule for to be a board member for third generations could be summarized as being minimum at the age of 30, having minimum 10 years business experience including minimum 2 years business experience in a different business preferably and minimum 2 years of executive role required. This chapter gives details about fundamental strategic management terms such as succession planning, growth policies, and organizational back-up strategies. 
The fourth chapter aims to clarify and protect future ownership rights of the family members by focusing on regulations about share transfer, profit share, protection and usage of the name and the brand of the family business and protection of family business assets' ownership and wealth management.

The last chapter gives details about the amendments, revisions and legislation of the constitution. The family constitution will be updated in every five years and it will be enacted after the acceptance of all parties of the family related. Appendices include the constitution of the family assembly, the constitution of the family council, the principles of the family council, the rules and the regulations of the advisory board, the duties and responsibilities of the advisory board, the essentials of board of directors, and lastly essentials of general assembly mechanism.

\section{DISCUSSION}

The first chapter of the family constitution examined within this paper, is mainly about general terms and conditions. Introduction, the purpose and the justification of the constitution, parties related with the constitution and necessary terms and conditions are stated. The second chapter gives details about the family values, corporate values as a family owned business, and family organs/organizations. The third chapter consists of the management of the family. Fourth chapter exhibits the organizations about family and business in terms of ownership. Last chapter gives information about the amendments and revisions of the constitution and the legislation date.

Supported with the data through the serial in-depth interviews with top executives and careful work on the family constitution, the aim of the constitution of the Company could be summarized as the elimination of ambiguities in terms of future generations of the family and the creation of an effective and efficient work climate and organizational structure for the survival and sustainability of the family business through clarifying the roles, duties and responsibilities of the shareholders and family members.

The Company gives the needed details about the terms and conditions including family businesses, co-founders, family assembly, family council, advisory board and related terms in the first chapter of the family constitution. It is evident that the family is successful with the transfer of family values to business values. Moreover, it could be stated that internal generative capability through value creation across generations, transgenerational entrepreneurship through establishing communication and succession planning are evident by examples in the family constitution. Third chapter gives details about fundamental strategic management terms such as succession planning, growth policies, and organizational back-up strategies. The fourth chapter aims to clarify and protect future ownership rights of the family members 
by focusing on protection of family business assets' ownership and wealth management. The last chapter gives details about the amendments, revisions and legislation of the constitution.

\section{CONCLUSION}

The governance of a family owned business is more complex than other forms of business due to family influence. The literature supports the crucial role of family governance and succession mechanisms in increasing business performance in different studies like Sacristan-Navarro and Cabeza-Garcia (2020) and Tobak et al. (2018). The lack of governance in family owned businesses creates organizational problems, therefore it is needed by the business, family and the ownership group in family business (Davies, 2001).

This paper is designed to explore the role of family constitutions for transgenerational entrepreneurship in family businesses by examining how family governance can strengthen the transgenerational entrepreneurship. Family entrepreneurship and transgenerational entrepreneurship research, a rapidly developing area, emphasizes the intersecting fields of family, family business and entrepreneurship (Hanson \& Keplinger, 2020:1). And also, this paper examined the role and influence of the family in realizing business performance. The family constitution of a family owned business located in İzmir, Turkey, was examined and qualitative methods were applied.

Although this paper contributes the literature theoretically about the succession of a family business, it analyzed only one family owned business in terms of family constitution and transgenerational entrepreneurship due to time constraint. The research findings support the previous literature in family governance. This paper also contributes the literature by highlighting the importance of the new systems theory that has not been systematically studied in family business literature. It could be claimed that this paper is one of the first works in the literature that connects new systems theory which is one of the most important tools to understand the individual and the society, to family businesses to set a theoretical foundation. New systems theory conceptualizes family business as a social system and provides an extensive understanding of the complexities of family businesses.

This paper has some limitations that should be addressed such as enriching by a hybrid research design including not only qualitative research methods, but also the quantitative methods. Future researchers could work on different family businesses in different regions, cities, or countries. Examining the relationship between personality, family governance perception, and entrepreneurial orientation of the family members could develop this paper. Future researchers could analyze the differences of family businesses in different industries. 


\section{KUŞAKLAR ARASI GİRIŞIMCİLİK VE AİLE ANAYASASI: KEŞİFSEL BİR ÖRNEK OLAY ANALIZİ}

\section{GÍRİŞ}

Dünya'da en yaygın olan iş örgütlenmesi aile işletmeleridir. Küresel çapta işletmelerin \%75 ila \%90'1, Avrupa' da ise işletmelerin \%70 ila \%80'i aile işletmelerinden oluşmaktadır (Yükselen \& Yıldız, 2014:15). Aile işletmeleri yazını, aile işletmelerinin sadece \%30'unun kurucusundan ikinci kuşağa geçişte hayatta kaldığını ortaya koymaktadır (Collins et al., 2016:52). Aile işletmelerinin Dünya'da sadece \%3'ü, üç ve daha fazla kuşağı görebilmektedir. Aile üyeleri arasında yönetişim eksikliği olması durumunda ailenin, aile işletmesi üzerinden bir yük haline geldiği görülmektedir (Suess-Reyes, 2017:750).

Aile yönetişimi, aile üyeleri arasında yapıcı tartışmalara, problem çözümüne ve karar vermeye zemin oluşturan, iletişimin doğru yürütülmesi ve öğretilmesi ile ilgili olan bir süreçtir. Aile anayasası, aile işletmeleri için en önemli kurumsal yönetişim adımlarından biri olmakla beraber, aile üyelerinin değer ve ilkelerini dokümente etmekte ve herhangi bir çatışma sebebiyle karar verme durumunda ailenin bütünlüğünü korumak adına stratejileri tanımlamaktadir.

Aile işletmelerinin doğası aile, mülkiyet ve iş gibi birbirinin içine geçen boyutlar sebebiyle karmaşıktır. Bu durum, akademinin derinlemesine analiz etme imkânı açısından ilginç bulduğu bir alandır. Bu çalışmanın amacı, aile işletmelerinde kuşaklar arası girişimcilik açısından aile anayasası ve yönetişim uygulamalarının rolünü analiz etmektir. Bu amaçla İzmir'de bulunan bir aile işletmesinin aile anayasası incelenmiş ve nitel araştırma yöntemlerinden derinlemesine mülakat ve örnek olay analizi tekniği kullanılmıştır. Çalışmanın ilerleyen bölümlerinde teorik çerçeve ve ilgili yazın araştırmasına yer verilmiş, ardından çalışma kapsamında ele alınan aile anayasasının karakteristiklerini ortaya koymayı amaçlayan keşifsel yaklaşım ile yapılan analizlere yer verilmiştir. Son bölümde ise tartışma ve sonuç bulunmaktadır.

\subsection{Teorik Çerçeve \& Yazın Araştırması}

\subsubsection{Aile Anayasası}

Aile anayasası, ailenin kendini nasıl yöneteceğini gösteren ve üzerinde anlaşı1lmış olan stratejik bir dokümandır (Koeberle-Scmid, 2018:139). Aile anayasası, aile ile iş ilişkilerini düzeneyen, strateji, yap1, kural ve prosedürlerin yer aldığg yazılı bir doküman üzerinde anlaşmaya varılmasıdır. Aile anayasası tüm aile bireyleri tarafından imzalanıp, onaylanır (Arteaga \& Menendez-Requejo, 2017:1). Aile anayasası, ailenin vizyonunu, değerlerini ve aile ile iş arasındaki çerçeveyi belgelemektedir (Jakob, 2020:9). Aile anayasası, aile üyelerinin karar alma 
süreçleri ve sorumluluklarının belirlenmesi ile ilgili zemin oluşturur ve ilkeleri tanımlamaktadır (Koeberle-Scmid, 2018:139).

\subsubsection{Yeni Sistem Teorisi}

Niklas Luhmann tarafından geliştirilen "autopoiesis" kavramı, yaşayan sistemlerde kendini yeniden üretme anlamına gelmektedir (Seidl, 2004:2). Yeni sistem teorisi bireyi ve toplumu anlamanın önemli araçlarından birisidir ve odağında insanı barındıran tüm disiplinler için bu teoriyi anlamak ve uygulamak önem taşımaktadır (Kurtaran-Öntaş \& Akçay, 2014). Yeni sistem teorisi, aile işletmelerini aile ve iş olarak yapılandırarak kavramsallaştırır. Yeni sistem teorisi aile işletmelerinin özelliklerinin ve karmaşıklıklarının kapsamlı bir şekilde anlaşılmasını sağlamaktadır.

\subsubsection{Kuşaklar Arası Girişimcilik}

Kuşaklar arası girişimcilik, Kaynak Tabanlı Yaklaşım’a (Resource-Based View) dayanmaktadır. Kuşaklar arası girişimcilik, "ailenin kendi geliştirdiği kaynak ve yeteneklerini yeni finansal ve sosyal değer yaratmak için nesiller boyunca kullanması ve girişimci zihniyet oluşturması” olarak tanımlanmaktadır (Suess-Reyes, 2017:753; Habbershon et al., 2010:1). Kuşaklar arası girişimcilik, tekrar tekrar ve zaman içinde hissedar değeri veya kârlılığı yerine; henüz doğmamış nesiller için geniş bir ekonomik ve sosyal değer kümesi oluşturmaya odaklanmaktadır (Nason et al., 2014:3-4). Kuşaklar arası girişimcilik, değerin sadece mevcut paydaşlar için değil, aynı zamanda gelecek aile kuşakları için nasıl yaratıldığına bakarak boylamsal bir bakış açısı benimsemektedir (Zellweger et al., 2012:137).

\section{YÖNTEM}

Bu çalışmada özel bir araştırma deseni kullanılmıştır. Çok katılımcılı, çok nesilli, tek vaka çalışması yaklaşımı kullanılmıştır (Genç \& İyigün, 2011:1128). Hidrolik ve pnömatik bileşenler endüstrisinde faaliyet gösteren bir aile işletmesinin üst düzey yöneticileri ile derinlemesine mülakatlar yapılmış, gözlem ve doküman/ arşiv kayıtları gibi farklı kaynaklardan veri toplanmıştır. İzmir'de bulunan bir aile işletmesinin aile anayasası incelenmiş ve nitel araştırma yöntemlerinden keşifsel örnek olay analizi uygulanmıştır.

\section{ARAŞTIRMA BULGULARI}

Araştırma kapsamında incelenen aile işletmesi, İzmir'de üç kardeş tarafından kurulan yüksek kaliteli ve uygun maliyetli hidrolik ve pnömatik elemanların üretiminde 35 yılı aşkın deneyime sahiptir. Bu üç erkek kardeşin toplam 5 çocuğu (1. erkek kardeş: 2 çocuk +2 . erkek kar- 
deş: 2 çocuk + 3. erkek kardeş: 1 çocuk) vardır. Bu çocuklardan sadece iki tanesi aile işletmesinde çalışmaktadır. Araştırma kapsamında aile işinde aktif olarak çalışan ve yönetim kurulu üyelikleri ile yönetici rolleri olan bu iki kişi ile derinlemesine mülakatlar gerçekleştirilmiştir.

Araştırma kapsamında analiz edilen aile işletmesinin altı aylık bir hazırlık döneminin (bir danışmanlık şirketi ve uzmanlar eşliğinde toplamda 18 ay) sonucunda hazırlanmış olan ve ekleri ile beraber 71 sayfadan oluşan bir aile anayasası bulunmaktadır ve 2018 yılında anayasa yürürlüğe girmiştir. Anayasanın genel şartlar ve koşullar, aileye ilişkin koşullar, aile ve iş arasındaki ilişkilere ilişkin koşullar, mülkiyet haklarına ve değişikliklerine ilişkin koşullar, aile anayasasının revizyon ve mevzuatını içeren 5 ana bölümü bulunmaktadır.

\section{TARTIŞMA}

Araştırma kapsamında analiz edilen aile anayasasının ilk bölümü genel şartlar ve koşullar ile ilgilidir. Giriş, anayasanın amacı ve gerekçesi, anayasa ile ilgili taraflar ve gerekli hüküm ve koşullar belirtilmiştir. İkinci bölümde aile değerleri, bir aile şirketi olarak kurumsal değerler ve aile organları hakkında ayrıntılar verilmektedir. Üçüncü bölüm ailenin yönetimi ile ilgili konulardan oluşmaktadır. Dördüncü bölüm, aile ve iş dünyası ile ilgili kuruluşlara mülkiyet açısından odaklanmaktadır. Son bölüm, anayasa ve mevzuat tarihlerindeki değişiklikler ve revizyonlar hakkında bilgi vermektedir.

Üst düzey yöneticilerle yapılan seri derinlemesine mülakatlar ve aile anayasası üzerinde özenli çalışmalar yoluyla elde edilen verilerle desteklenen aile anayasasının amacı, ailenin gelecek nesillerinde belirsizliklerin ortadan kaldırılması ve hissedarların ve aile üyelerinin rollerini, görevlerini ve sorumluluklarını açıklığa kavuşturmak suretiyle aile şirketlerinin sürdürülebilirliği için etkili ve verimli bir çalışma ortamı ve organizasyon yapısı oluşturmak olarak ifade edilebilir.

\section{SONUÇ}

Bir aile işletmesinin yönetiminin, ailenin sahip olduğu merkezi rol ve liderliği sebebiyle aile işletmesi olmayan işletmelere göre daha karmaşık olduğu kabul edilmelidir. Bu çalışma, aile yönetişiminin ve kimliğinin, kuşaklar arası girişimciliğin güçlendirilmesine nasıl katkıda bulunabileceğini inceleyerek kuşaklar arası girişimcilik için aile anayasalarının rolünü araştırmak üzere tasarlanmıştır. Ayrıca, bu çalışma, ailenin finansal ve sosyal performansa ulaşmasındaki rolünü ve kuşaklar arası girişimcilik açısından etkisini incelemiştir.

Bu çalışma zaman kısıtı sebebi ile sadece bir aile işletmesi ve aile anayasası üzerinde yapılmıştır. Bu çalışma sadece nitel araştırma yöntemlerini değil, aynı zamanda nicel yöntemleri 
de içeren hibrit bir araştırma tasarımı ile zenginleştirilebilir. Gelecek araştırmacılar, farklı bölgeler, şehirler veya ülkelerdeki farklı aile şirketleri üzerinde çalışabilirler. Kişilik, aile yönetişimi algısı ve aile üyelerinin girişimci yönelimi arasındaki ilişkiyi incelemek ve farklı sektörlerdeki aile şirketlerinin farklılıklarını analiz etmek de gelecek araştırmacılara önerilebilir.

\section{REFERENCES}

Arteaga, R. \& Menendez-Requejo, S. (2017). Family Constitution and Business Performance: Moderating Factors. Family Business Review, 30(4), 1-19.

Berent-Braun, M. M. \& Uhlaner, L. M. (2012). Family Governance Practices and Teambuilding: Paradox of the Enterprising Family. Small Business Economics, 38, 103-119.

Bhatnagar, N. (2019). Family Togetherness. Asian Management Insights, 6(1), 26-31.

Chang, Y. \& Luo, Z. (2013). Endogenous Division Rules as a Family Constitution: Strategic Altruistic Transfers and Sibling Competition. Journal of Population Economics, 28(1), 173-194.

Collins, J.D., Worthington, W.J. \& Schoen, J.E. (2016). Family Business CEO Succession: Examining Personal Retirement Expectations. Journal of Small Business Strategy, 26(2), 51-70.

Dao, B.A.K. (2018). "Danny Miller (1983) and the Emergence of the Entrepreneurial Orientation (EO) Construct" in G. Javadian et al. (eds.), Foundational Research in Entrepreneurship Studies, London, UK: Palgrave Macmillan.

Davies, J. (2019). Preventing and Solving Issues in Family-Run Businesses. NRC, 21(3), 168-171.

Davies, J. (2001). Governing the Family-Run Businesses. HBS Working Knowledge: Business Research for Business Leaders, https:/hbswk.hbs.edu/item/governing-the-family-run-business (Accessed: 10/08/2019).

Dirin, F. \& Tutan, M.U. (2015). Ekonomik Krizlerin Ardından Büyük Aile İşletmesi Anayasası: İzmir İli Merkezli Üç Aile İşletmesi Örneği. Journal of Yaşar University, 10(38), 6478-6554.

Genç, N. \& İyigün, N.Ö. (2011). The Role of Organizational Learning and Knowledge Transfer in Building Strategic Alliances: A Case Study. Procedia - Social and Behavioral Sciences, 24, 1124-1133.

Gonzalez L. \& K. Ramachandran (eds), Exploring Transgenerational Entrepreneurship: The Role of Resources and Capabilities, Cheltenham, UK and Northampton, MA, USA: Edward Elgar Publishing.

Habbershon, T.G.; Nordqvist, M. \& Zellweger M. (2010). “Transgenerational Entrepreneurship" in M. Nordqvist \& T.M. Zellweger (eds), Transgenerational Entrepreneurship: Exp- 
loring Growth and Performance in Family Firms Across Generations, Cheltenham, UK and Northampton, MA, USA: Edward Elgar Publishing.

Habbershon, T.G. \& Pistrui, J. (2002). Enterprising Families Domain: Family-Influenced Ownership Groups in Pursuit of Transgenerational Wealth. Family Business Review, 15(3), 223-237.

Hanson, S. K. \& Keplinger, K. (2020). The Balance that Sustains Benedictines: Family Entrepreneurship Across Generations. Entrepreneurship \& Regional Development, UK: Taylor \& Francis Online, 1-15.

İyigün, N.Ö. (2015). What could Entrepreneurship do for Sustainable Development? A Corporate Social Responsibility-Based Approach. Procedia - Social and Behavioral Sciences, 195, 1226-1231.

Jakob, D. (2020). The Role of Foundations in Family Governance. Trusts \& Trustees, 26(1), 4-10. Jaskiewicz, P.; Combs, J.G. \& Rau, S.B. (2015). Entrepreneurial Legacy: Toward a Theory of How Some Family Firms Nurture Transgenerational Entrepreneurship, Journal of Business Venturing, 30(1), 29-49.

Kellermanns, F.W.; Eddleston, K.A.; Sarathy, R. \& Murphy, F. (2012). Innovativeness in Family Firms: A Family Influence Perspective. Small Business Economics, 38(1), 85-101.

Koeberle-Schmid, A. (2018). "Organizing the Family: Family Governance” in B. Cannessa, J. Escher, A. Koeberle-Scmid, P. Preller \& C. Weber (eds), The Family Office: A Practical Guide to Strategically and Operationally Managing Family Wealth, Switzerland: Palgrave Macmillan.

Kurtaran-Öntaş, Ö. \& Akçay, S. (2014). Niklas Luhmann'ın Sistem Teorisi ve Teorinin Sosyal Hizmet Disiplinindeki Yansımaları. Toplum ve Sosyal Hizmet, 25(2), 97-110.

Luhmann, N. (1984). Soziale Systeme: Grundriß Einer Allgemeinen Theorie, Suhrkamp: Frankfurt.

Lumpkin, G.T. \& Dess, G.G. (1996). Clarifying the Entrepreneurial Orientation Construct and Linking it to Performance. Academy of Management Review, 21(1), 135-172.

Maturana, H. (1980). Autopoiesis and Cognition, Reidel, Dordrecht.

Montemerlo, D. \& Ward, J.L. (2005). The Family Constitution: Agreements to Secure and Perpetuate Your Family and Your Business, London, UK: Palgrave Macmillan.

Mustakallio, M.; Autio, E. \& Zahra, S.A. (2002). Relational and Contractual Governance in Family Firms: Effects on Strategic Decision Making. Family Business Review, 15(3), 205-222.

Nason, R.S.; Gonzalez L.A.C. \& Sharma, P. (2014). "Introduction: Exploring Transgenerational Entrepreneurship: The Role of Intangible Resources” in P. Sharma, P. Sieger, R.S. Nason, A.C.G. Leon and K. Ramachandran (eds), Exploring Transgenerational Entrepreneurship: The Role of Resources and Capabilities, UK: Edward Elgar. 
Ramadani, V., Memili, E., Palalic, R. \& Chang, E. P. C. (2020). "Governance in the Family Business" in V. Ramadani, E. Memili, R. Palalic \& E. P. C. Chang (eds), Entrepreneurial Family Business, Switzerland: Springer.

Randerson, K.; Bettinelli, C.; Fayolle, A. \& Anderson, A. (2015). Family Entrepreneurship as a Field of Research: Exploring Its Contours and Contents. Journal of Family Business Strategy, 6(3), 143-154.

Sacristan-Navarro, M. \& Cabeza-Garcia, L. (2020). When Family Firm Corporate Governance Fails: The Case of El Corte Inglés. Journal of Family Business Management, 10(2), 97-115.

Scherrer, S. \& Astrachan, C.B. (2018). "Sustainable Entrepreneurship: Family Firms as Sustainability Pioneers" in R. Altenburger (eds), Innovation Management and Corporate Social Responsibility: Social Responsibility as Competitive Advantage, Switzerland: Springer.

Schumpeter, J.A. (1934). The Theory of Economic Development, Cambridge, MA: Harvard University Press.

Seidl, D. (2004). Luhmann's Theory of Autopoietic Social Systems. Müncher Betriebswirtschaftliche Beiträge Munich Business Research, Germany: LMU München.

Sorenson, R. L. (2014). Values in Family Business in L. Melin, M. Nordqvist, \& P. Sharma (eds), SAGE Handbook of Family Business, London: SAGE.

Suess-Reyes, J. (2017). Understanding the Transgenerational Orientation of Family Businesses: The Role of Family Governence and Business Family Identity. Journal of Business Economics, 87(6), 749-777.

Tobak, J.; Nagy, A.; Petö, K.; Fenyves, V. \& Nabradi, A. (2018). The Main Factors Determining Effective Operation in Case of a Family Business. International Journal of Entrepreneurial Behavior \& Research, 24(6), 1065-1074.

Wulf, V. (1999). Evolving Cooperation when Introducing Groupware: A Self-Organization Perspective. Cybernetics \& Human Knowing, 6(2), 55-75.

Yükselen, C. \& Yıldız, E. (2014). The Role of Family Constitution in Sustainability of Family Businesses and Evaluation in light of Implementation Problems. Research Journal of Business and Management, 1(1), 14-28.

Zahra, S.A. (2005). Entrepreneurial Risk Taking in Family Firms. Family Business Review, $18(1), 23-40$.

Zellweger, T.M.; Nason, R.S. \& Nordqwist M. (2012). From Longevity of Firms to Transgenerational Entrepreneurship of Families: Introducing Family Entrepreneurial Orientation. Family Business Review, 25(2), 136-155. 


\section{APPENDIX}

About the company: The Company has over 35 years experience in manufacturing high quality and cost-effective hydraulics and pneumatic components. Hydraulics pipe clamps represent about $70 \%$ of the company business while recent investments are progressively supporting the growth of other components like plastic tapered plugs, hydraulic tank covers, level gauges, u-bolts, metal pipe clamps. Hydraulic Pipe Clamps are manufactured according to international standards and grant quick and easy pipes and hoses installation together with a clean and rational pipeline. The use of Hydraulic Pipe Clamps reduces significantly noise and vibration on the machinery having a direct effect on the users health and safety. While applications of Hydraulic Pipe Clamps are boundless, most frequent field of utilization are operating machineries, marine hydraulics, energy transfer lines, construction and agriculture machineries. The Company seeks for providing the best quality products and solutions to its customers including plastic plugs, hydraulic tank cover and level indicators by increasing the production capacity and product diversity (Company web site, 2019).

\begin{tabular}{|c|c|c|}
\hline $\begin{array}{c}\text { KATKI ORANI / } \\
\text { CONTRIBUTION RATE }\end{array}$ & AÇIKLAMA / EXPLANATION & $\begin{array}{c}\text { KATKIDA BULUNANLAR / } \\
\text { CONTRIBUTORS }\end{array}$ \\
\hline $\begin{array}{c}\text { Fikir veya Kavram / Idea } \\
\text { or Notion }\end{array}$ & $\begin{array}{c}\text { Araştırma hipotezini veya fikrini } \\
\text { oluşturmak / Form the research hypothesis } \\
\text { or idea }\end{array}$ & Doç. Dr. N. Öykü IYYIGÜN \\
\hline Tasarım / Design & $\begin{array}{c}\text { Yöntemi, ölçeği ve deseni tasarlamak / } \\
\text { Designing method, scale and pattern }\end{array}$ & Doç. Dr. N. Öykü IYİGÜN \\
\hline $\begin{array}{c}\text { Veri Toplama ve İşleme } \\
\text { / Data Collecting and } \\
\text { Processing }\end{array}$ & $\begin{array}{c}\text { Verileri toplamak, düzenlenmek ve } \\
\text { raporlamak / Collecting, organizing and } \\
\text { reporting data }\end{array}$ & Doç. Dr. N. Öykü IYİGÜN \\
\hline $\begin{array}{c}\text { Tartı̧ma ve Yorum } \\
\text { / Discussion and } \\
\text { Interpretation }\end{array}$ & $\begin{array}{c}\text { Bulguların değerlendirilmesinde ve } \\
\text { sonuçlandırılmasinda sorumluluk almak } \\
\text { / Taking responsibility in evaluating and } \\
\text { finalizing the findings }\end{array}$ & Doç. Dr. N. Öykü IYIGÜN \\
\hline $\begin{array}{c}\text { Literatür Taramas1 / } \\
\text { Literature Review }\end{array}$ & $\begin{array}{c}\text { Çalışma için gerekli literatürü taramak / } \\
\text { Review the literature required for the study }\end{array}$ & Doç. Dr. N. Öykü IYIIGÜN \\
\hline
\end{tabular}


